\title{
Exogenous GnRH induces ovulation in seasonally anoestrous lactating goats (Capra hircus)
}

\author{
C. H. Knight, C. J. Wilde, B. J. McLeod*† and W. Haresign* \\ Hannah Research Institute, Ayr KA6 5HL, U.K.; and *AFRC Research Group on Hormones and \\ Farm Animal Reproduction, University of Nottingham, School of Agriculture, Sutton Bonington, \\ Loughborough, Leics LE12 5RD, U.K.
}

\begin{abstract}
Summary. A specific sheep LH radioimmunoassay was validated for the measurement of goat $\mathrm{LH}$, and used to monitor luteal-phase $\mathrm{LH}$ episodes and the preovulatory $\mathrm{LH}$ surge in progestagen sponge-synchronized cycling goats. No luteal-phase LH episodes were detected during $12 \mathrm{~h}$ of frequent (15-min) blood sampling in 2 goats. A preovulatory LH surge was recorded in $5 / 5$ goats, with a mean amplitude of $45.4 \pm 7.2 \mathrm{ng} / \mathrm{ml}$ and a mean time of onset of $38.4 \pm 1.2 \mathrm{~h}$ after removal of a progestagen-impregnated sponge. In anoestrous goats, single i.v. injections of 1000 and $2000 \mathrm{ng} \mathrm{GnRH}$ induced LH episodes with a mean amplitude of $2.04 \pm 0.11$ and $3.67 \pm 0.06 \mathrm{ng} / \mathrm{ml}$ respectively, but injections of 250 or $500 \mathrm{ng}$ did not consistently elevate LH concentrations. Progestagenprimed, seasonally anoestrous lactating goats were treated with repeated injections of $1500 \mathrm{ng}$ GnRH (every $2 \mathrm{~h}$ for 52 or $78 \mathrm{~h}$ ) in May 1985 or 1986. All 10 had kidded in March of the same year, and were consequently at peak lactation at the time of GnRH treatment. A preovulatory LH surge was detected in 9 goats with a mean time of onset of $59.5 \pm 2.9 \mathrm{~h}(1985)$ or $39.6 \pm 3.3 \mathrm{~h}$ (1986) after vaginal sponge removal. All animals displayed oestrus and ovulated, and 9 of the goats were mated: in 5 of these animals pregnancies were successfully carried to term.

The results show episodic LH release in response to GnRH and indicate that ovulation can be induced in seasonally anoestrous goats, even at peak lactation, and normal pregnancies may result.
\end{abstract}

Keywords: goats; LH; GnRH; induced oestrus

\section{Introduction}

Under normal British management conditions, Saanen goats are seasonal breeders which mate during October and November and kid during March and April (gestation length 150 days). Since this seasonality imposes constraints on milk production systems, the ability to breed a proportion of animals out of the normal breeding season could be highly beneficial. Manipulation of photoperiod (introduction of long days during winter) will advance the start of the breeding season (by about 10 weeks; BonDurant et al., 1981) and ovulation can be induced in anoestrous goats by using progesterone priming followed by treatment with pregnant mare's serum gonadotrophin (PMSG; Ritar et al., 1984). This treatment is not generally effective before the 20th week of lactation (Corteel, 1975) and so the season is advanced by only about 10 weeks. Our intention was to breed lactating goats at the time of peak milk yield some 20 weeks before the normal breeding season.

$†$ Present address: Cattle and Sheep Production Department, AFRC Institute for Grassland and Animal Production, Hurley, Maidenhead, Berkshire SL6 5LR, U.K. 
Repeated injections or continuous infusion of gonadotrophin-releasing hormone (GnRH) elevate plasma LH concentrations in seasonally anoestrous ewes and this in turn stimulates follicle growth and induces normal ovulations (McLeod et al., 1982a, b, 1983) which are associated with good fertility (McLeod \& Haresign, 1984). The aim of this study was to determine whether GnRH treatment would also be effective in elevating plasma LH concentrations in goats, and whether this would ultimately result in normal ovulation in animals that were at peak lactation.

\section{Materials and Methods}

Animals. All the goats studied were Saanens, which were housed indoors and exposed to natural lighting conditions at a latitude of $55.5^{\circ} \mathrm{N}$ in southwest Scotland. Billy goats were housed separately from nannies, but were within olfactory and auditory range. All animals were fed a concentrate diet (goat mix 2, Edinburgh School of Agriculture) twice daily, and hay and water were available ad libitum. Lactating goats were milked twice daily, at 07:00 and 16:00 h. All goats were fitted with an indwelling jugular catheter, at least $24 \mathrm{~h}$ before the experiment started.

Validation of LH assay. Five goats (4 in Week 30 of lactation, 1 non-lactating) were studied during the normal breeding season in October 1984. Jugular vein blood samples $(2 \mathrm{ml})$ for analysis of $\mathrm{LH}$ were taken via an indwelling catheter, at 15 -min intervals for $12 \mathrm{~h}$ from 2 goats during the luteal phase of the oestrous cycle $(9$ days after last observed oestrus). To synchronize ovulation, a sponge containing $30 \mathrm{mg}$ fluorogestone acetate (Chronogest: Intervet Laboratories, Cambridge, U.K.) was inserted intravaginally into all 5 goats 10 days after observed oestrus and removed 12 days later. Blood samples were taken from each goat, at 2-h intervals, for $64 \mathrm{~h}$ commencing $12 \mathrm{~h}$ after sponge removal. A billy goat was introduced into each pen at approximately 5 -h intervals, and the time of standing oestrus was recorded.

Determination of GnRH dose. Four yearling goats were used in March 1985. All had an intravaginal progestagenimpregnated sponge in place throughout the experiment. Jugular vein blood samples $(2 \mathrm{ml})$ for analysis of $\mathrm{LH}$ were collected from an indwelling catheter at 15 -min intervals for $10 \mathrm{~h}$ on each of 2 consecutive days. GnRH (Lutal; Fabwerke Hoechst AG, Frankfurt, West Germany) in $1 \mathrm{ml}$ sterile $0.154 \mathrm{M}-\mathrm{NaCl}$ was administered via the catheter every $2 \mathrm{~h}$ during the last $8 \mathrm{~h}$ of the sampling period (4 injections per animal). Each goat was randomly allocated to one of 4 dose levels of GnRH on the first day, and to a different dose on the second day. The dose levels were 250, 500, 1000 and $2000 \mathrm{ng} /$ injection.

Induction of ovulation in anoestrous lactating goats. Four goats which kidded in the last week of March 1985 were used. Hand milking began within 3 days of parturition. A progestagen-impregnated sponge was placed intravaginally in each goat during Week 7 of lactation, and 3 days later each goat underwent laparoscopy to assess ovarian activity. Intravaginal sponges were removed after 9 days (in Week 8 of lactation, during the 4th week of May), and blood sampling (for LH analysis) and GnRH treatment was started at the same time. Sampling began 15 min before sponge removal and was repeated at 15 -min intervals (frequent sampling) for $10 \mathrm{~h}$ during the first and second days, and at $2-\mathrm{h}$ intervals (infrequent sampling) during each night and the third and fourth days. Sampling ended $80 \mathrm{~h}$ after sponge removal. Injections of $1500 \mathrm{ng} \mathrm{GnRH}$ in $1 \mathrm{ml}$ sterile saline $(0.154 \mathrm{M}-\mathrm{NaCl})$ were given i.v. at 2 -h intervals from $2 \mathrm{~h}$ after sponge removal until the end of the sampling period. A billy goat was introduced into each animal's pen at approximately 5-h intervals, standing oestrus was recorded and mating was allowed to occur. Laparoscopy was repeated 4 days after the treatment finished, and any corpora lutea were counted. Single samples of jugular venous blood were taken by venepuncture at bi-weekly intervals for 5 weeks after the GnRH treatment period, for analysis of progesterone.

The treatment was repeated during the following year in 6 goats. Laparoscopies were not performed, and blood sampling was at 2-h intervals only, except in one goat which was sampled at 15 -min intervals during the firşt day of GnRH treatment. Other details were as before. Five goats served as controls during the second year. One of these (Goat B13) had also been used as a control animal during the first year. All were treated in exactly the same way as the experimental animals (including frequent blood sampling), except that they received the saline vehicle alone. In addition, frequent blood samples were obtained during a 6 -h period one day before the progestagen sponges were removed in these 5 control animals and in one experimental animal.

Radioimmunoassays. Plasma LH concentrations were determined using the specific ovine double-antibody technique of Foster \& Crighton (1974) as modified by McLeod et al. (1982a). Serial dilutions of 2 goat plasmas ran parallel to the standard curve and to sheep plasma in this radioimmunoassay (Fig. 1). The limit of sensitivity was $0 \cdot 1-0 \cdot 2 \mathrm{ng} / \mathrm{ml}$, and non-specific binding was less than $3 \%$. Plasma progesterone concentrations were determined using a double-antibody technique supplied in kit form by Cambridge Medical Diagnostics, Bournemouth, U.K. The limit of sensitivity was $0.06 \mathrm{ng} / \mathrm{ml}$. Inter- and intra-assay coefficients of variation were $<10 \%$ in both assays.

Analysis of data. An LH episode was defined by the criteria of McLeod et al. (1982a); i.e. (i) an increase of at least $50 \%$ above the preceding baseline, (ii) at least two sample points between the peak value and the succeeding trough or baseline and (iii) a rate of decline in concentrations after the peak value no greater than the known half-life of the hormone in the sheep. Statistical analysis was by Student's $t$ test for paired or unpaired observations. 


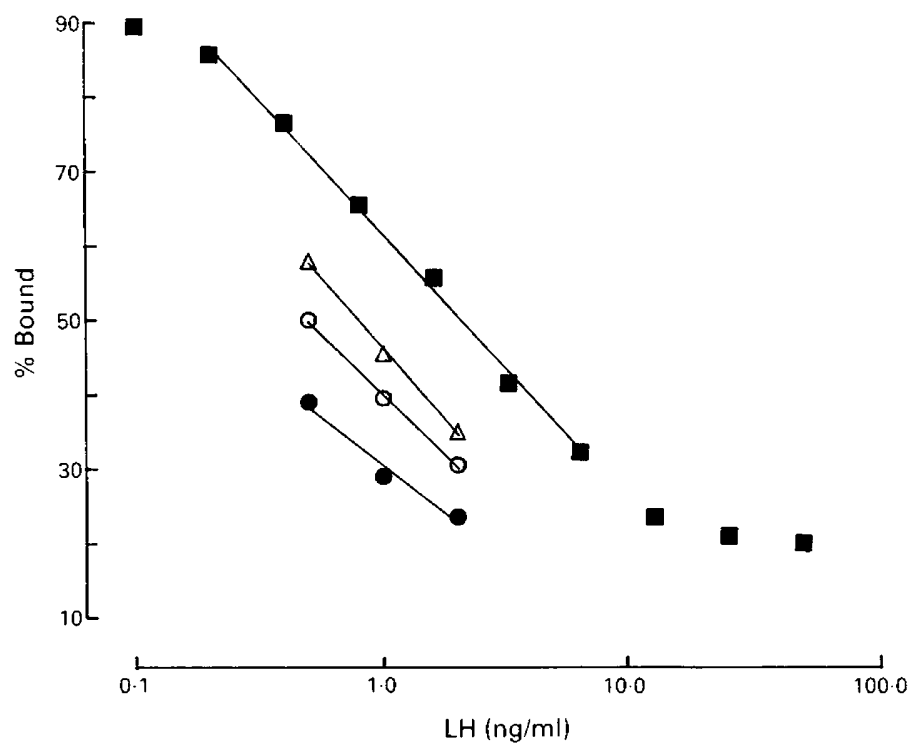

Fig. 1. Inhibition curves of serial dilutions of goat plasmas $(O, \odot)$ and sheep plasma $(\triangle)$ showing parallelism with standard ovine LH (NIH S-24), $\mathbf{a}$ ). See text for details.

\section{Results}

\section{Validation of LH assay}

The pattern of $\mathrm{LH}$ release during a normal oestrous cycle was investigated. $\mathrm{LH}$ concentrations remained low, at about the limit of sensitivity of the assay $(0.1-0.2 \mathrm{ng} / \mathrm{ml})$ throughout $12 \mathrm{~h}$ of 15 -min blood sampling in the 2 goats studied in the luteal phase of the oestrous cycle (data not shown). No episodic LH release was detected at this time. Five goats were blood sampled at 2-h intervals for $52 \mathrm{~h}$ during the follicular phase of the oestrous cycle, after synchronization with intravaginal sponges. The baseline value of LH was above the limit of sensitivity in all 5 goats (mean \pm s.e.m., $0.54 \pm 0.07 \mathrm{ng} / \mathrm{ml}$ ). A preovulatory surge of $\mathrm{LH}$ was recorded in all 5 goats, and this occurred at a mean time of onset of $38.4 \pm 1.2 \mathrm{~h}$ after sponge removal. The mean duration of the surge was $13 \pm 0.7 \mathrm{~h}$ and the mean peak height was $45.4 \pm 7.2 \mathrm{ng} / \mathrm{ml}$.

\section{Determination of GnRH dose}

Of the 2 goats treated with $250 \mathrm{ng} \mathrm{GnRH} /$ injection one animal failed to show $\mathrm{LH}$ release. In the other, $\mathrm{LH}$ episodes (mean maximum conc. $1.52 \pm 0.3 \mathrm{ng} / \mathrm{ml}$ ) were recorded in response to 3 of the $4 \mathrm{GnRH}$ injections. This between-animal variation was also evident in goats treated with $500 \mathrm{ng}$ $\mathrm{GnRH} /$ injection, with one animal failing to respond and the other responding to all 4 injections (mean maximum conc. $1.46 \pm 0.27 \mathrm{ng} / \mathrm{ml}$ ). In all animals given the two higher doses of $\mathrm{GnRH}$ there was an LH episode associated with each GnRH injection (mean maximum conc. $2.04 \pm$ $0.11 \mathrm{ng} / \mathrm{ml}$ and $3.67 \pm 0.60 \mathrm{ng} / \mathrm{ml}$ for $1000 \mathrm{ng}$ and $2000 \mathrm{ng} \mathrm{GnRH}$, respectively). Endogenous LH episodes were apparent in 4 of the 8 goats (see Fig. 2).

\section{Induction of ovulation in anoestrous lactating goats}

A total of 10 goats were treated with GnRH during two consecutive seasons and a further 5 saline-treated goats acted as control animals. Four treated and one control goat were subjected to 


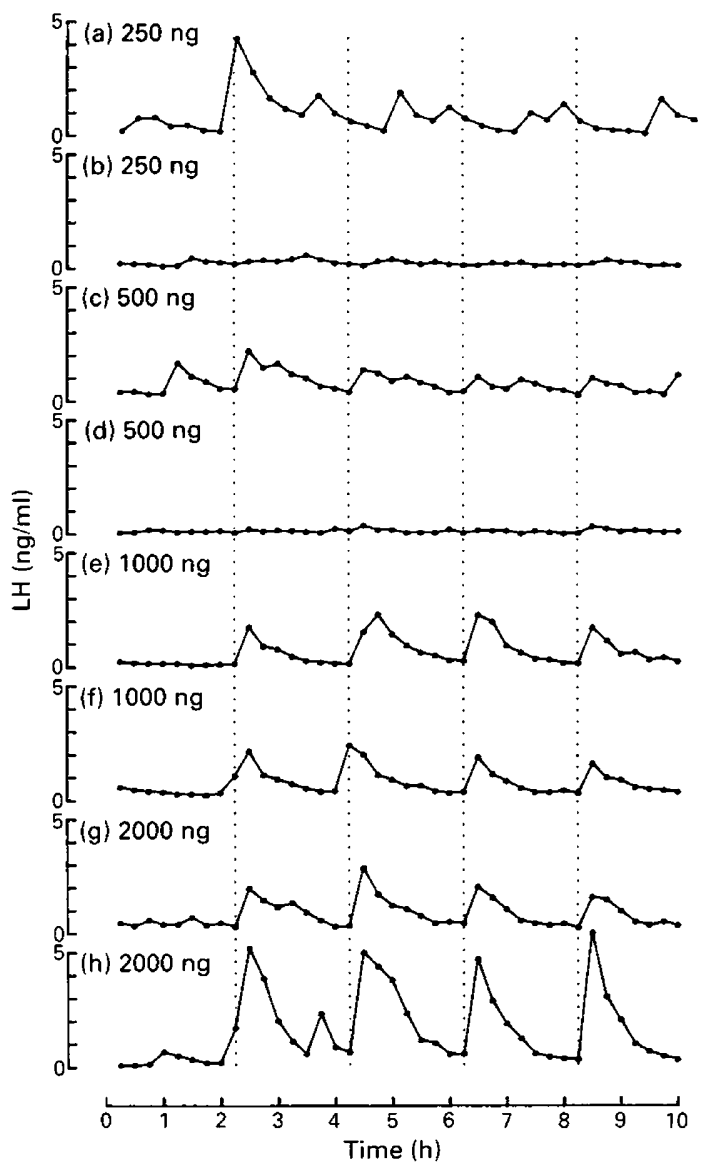

Fig. 2. $\mathrm{LH}$ release in anoestrous goats in response to four different doses of $\mathrm{GnRH} /$ injection. Blood samples were taken at 15 -min intervals, and $\mathrm{GnRH}$ was injected at 2 -h intervals, indicated by vertical dotted lines.

laparoscopy during the progesterone pre-treatment period, before GnRH or saline treatment. All animals showed some evidence of follicular development but none had recently ovulated (corpora lutea were not present). Six goats ( 5 controls, 1 treated) were blood sampled at 15 -min intervals for $6 \mathrm{~h}$ on the day before progestagen sponges were removed. Two of these demonstrated baseline levels of LH throughout, with no LH episodes apparent, whereas one goat exhibited a single episode (peak height $2.06 \mathrm{ng} / \mathrm{ml}$ and $90 \mathrm{~min}$ duration). The remaining 3 goats exhibited fluctuating $\mathrm{LH}$ concentrations between 0.1 and $1.0 \mathrm{ng} / \mathrm{ml}$, in which no clear episodes could be discerned.

Of the 10 goats which received $\mathrm{GnRH}, 4$ were blood sampled at 15-min intervals during the first and second days of treatment. All 4 animals demonstrated episodic LH release in response to GnRH (see Fig. 3a). GnRH-induced LH episodes were significantly reduced in amplitude on the second day $(7.02 \pm 0.67$ versus $3.38 \pm 1.05 \mathrm{ng} / \mathrm{ml}$, for Day 1 and Day 2 of treatment; $P<0.05)$. A preovulatory LH surge was recorded in 9 of the $10 \mathrm{GnRH}$-treated goats. In the first season this occurred at a mean of $59.5 \pm 2.9 \mathrm{~h}$ after progestagen sponge removal. In the second season the mean time of onset of the surge was earlier in the 5 animals in which it was detected $(39.6 \pm 3 \cdot 3 \mathrm{~h}$ after sponge removal: $P<0.01$ versus first season; Fig. 3a). The sixth animal treated in this season (in which an LH surge was not recorded) exhibited oestrus and was mated at $46 \mathrm{~h}$ after the start of treatment. In this animal an LH surge may have occurred after sampling was discontinued at $52 \mathrm{~h}$. 

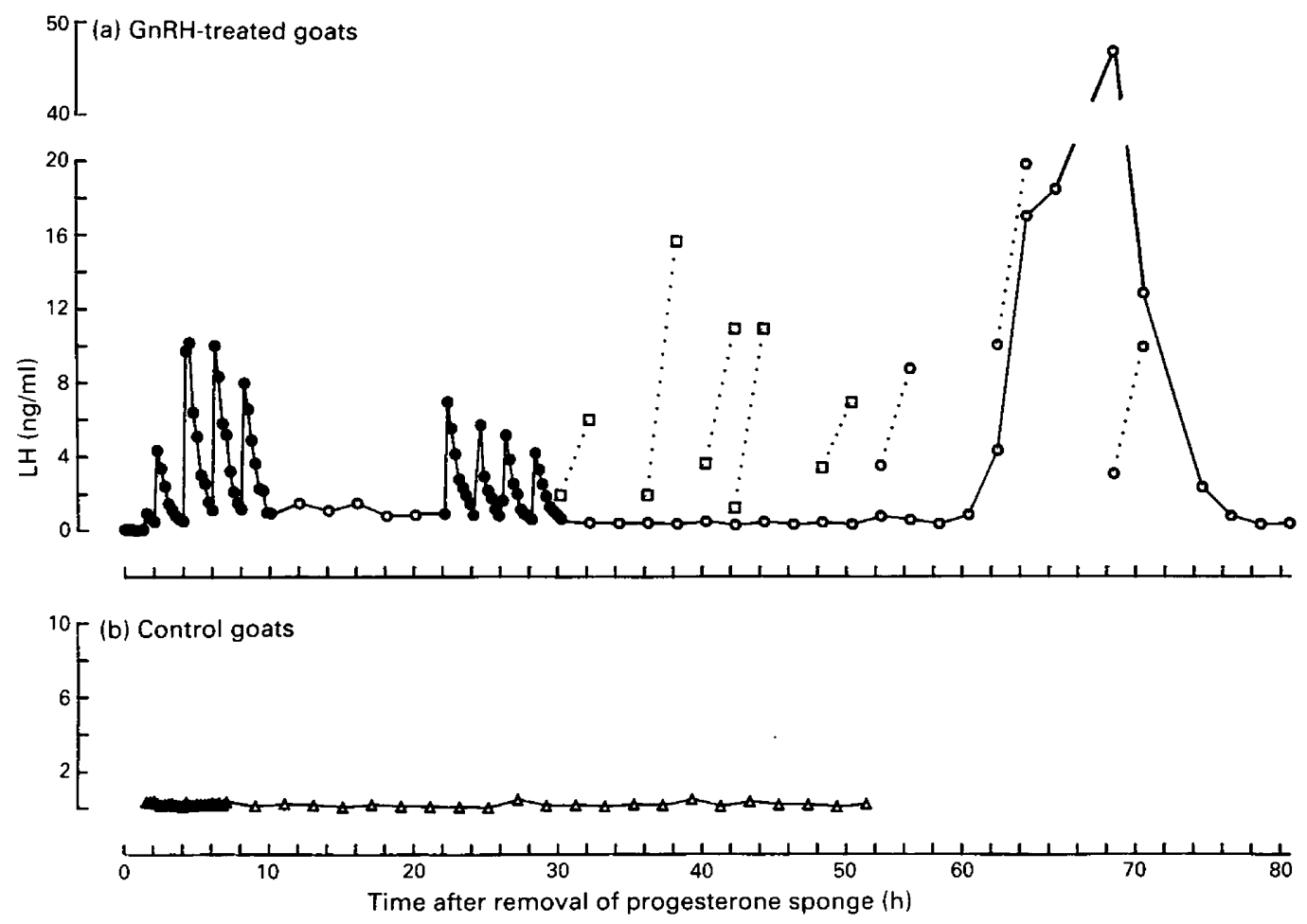

Fig. 3. LH release in anoestrous lactating goats given multiple injections of GnRH (1500 ng/ injection) (a) or saline vehicle (b). Blood samples were taken at 15 -min intervals $(\Delta)$ or $2-\mathrm{h}$ intervals $(O \square \triangle)$. GnRH or saline was injected at 2-h intervals, at each time point apart from time zero. A complete profile is shown for one GnRH-treated goat (a, solid line). Also shown is the start of the preovulatory LH surge for the remaining 3 goats treated with GnRH in the first season $(\mathrm{a}, \mathrm{O} \cdots \mathrm{O})$, and for the $5 \mathrm{GnRH}$-treated goats in which a surge was detected in the second season, when sampling ended at $52 \mathrm{~h}$ (a, $\square \cdots \square$ ). A complete profile for one salineinjected control goat from the second season is shown in (b).

The 4 goats examined by laparoscopy after GnRH treatment had all ovulated and, with the exception of 1 animal in which 2 corpora lutea were visible, all had triple ovulations. All 10 treated goats were mated, but only 5 successfully carried a pregnancy to term: 3 of these gave birth to twins, 1 to triplets and the fifth animal had still-born twins, which had been dead in utero for about 1 week. Of the remaining 5 goats, progesterone concentration declined on about Day 18 in 3 goats and on about Day 50 in the other 2 (Fig. 4).

None of the 5 control goats monitored in the second season showed any consistent $\mathrm{LH}$ release in response to injections of saline or exhibited preovulatory surge release of LH (Fig. $3 b$ ). LH episodes were seen in 2 goats during the 10-h period of 15 -min sampling, but only 1 of 3 episodes was associated with a saline injection. One control goat which had not shown episodes did exhibit oestrus, $50 \mathrm{~h}$ after the start of saline treatment. A preovulatory surge may have occurred after sampling finished. This same goat had been used as a control animal in the first season, when she had also exhibited oestrus. In this case a preovulatory surge was recorded (at $50 \mathrm{~h}$ ), but at laparoscopy no corpora lutea were present. There was, however, a corpus albicans present and this observation, along with the progesterone profile, suggested that ovulation did occur, but that the single corpus luteum regressed within 4 days after oestrus. 


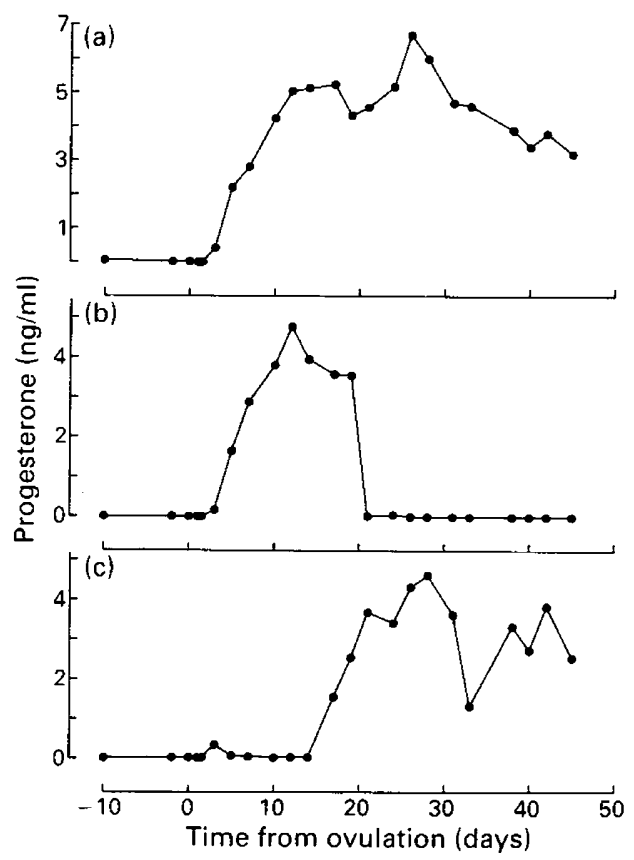

Fig. 4. Examples of progesterone profiles of lactating goats induced to ovulate with GnRH $(a, b)$ or injected with saline (c). The goat shown in (a) was treated with GnRH (Fig. 3a), ovulated, mated, conceived and carried a pregnancy to term. The goat shown in (b) was also treated with GnRH and ovulated but did not conceive. The goat shown in (c) was the one control goat which was injected with saline in the first season. She demonstrated oestrus and ovulated, but with abnormal luteal function. She returned spontaneously to oestrus after a short cycle of 10 days. The subsequent maintenance of a high progesterone concentration is suggestive of a persistent corpus luteum, since she was not mated at the induced or the spontaneous oestrus.

\section{Discussion}

A specific sheep LH assay has been used by others for the determination of goat $\mathrm{LH}$ (BonDurant $e$ al., 1981; Chemineau et al., 1982). We have confirmed the validity of this approach; serial dilutions of goat plasma ran parallel to sheep plasma and to a standard LH curve, and non-specific binding was less than $3 \%$. We used the assay to measure LH in anoestrous and luteal-phase goats. Anoestrous sheep have a basal LH concentration similar to that found during the luteal phase, but less frequent episodes of increased LH release (Baird et al., 1976; Scaramuzzi \& Baird, 1977). The pattern may be rather different in the goat. LH was detectable at low levels in anoestrous goats but undetectable during the luteal phase, and endogenous episodes of $\mathrm{LH}$ release were observed in anoestrous goats but not in luteal-phase goats. In the follicular phase, the preovulatory LH surge was highly synchronized between goats, with a time of onset after sponge removal similar to that obtained by Ritar $e t$ al. (1984).

The lowest dose of GnRH which consistently induced $\mathrm{LH}$ release was $1000 \mathrm{ng}$. This is higher than has previously been observed for lactating, seasonally anoestrous sheep, in which doses as small as $75 \mathrm{ng}$ are effective (McLeod et al., 1982a). The magnitude of the response to $1500 \mathrm{ng}$ in goats (mean LH pulse amplitude of $7.02 \pm 0.67 \mathrm{ng} / \mathrm{ml}$ on Day 1 of treatment) was similar to that produced by $250 \mathrm{ng}$ in sheep of a similar body weight, i.e. the goat requires 6 times as much GnRH as the sheep. Of 4 goats treated with 250 or $500 \mathrm{ng} \mathrm{GnRH,} 2$ responded and 2 did not. Part of this between-animal variability may be related to attenuated effects of previous GnRH treatment. The 
two responders were both being treated for the first time, whereas the two non-responders had both received 4 injections of a higher dose of $\mathrm{GnRH}$ on the previous day. In sheep, LH pulse amplitude decreases after the third or fourth injection of GnRH (McLeod et al., 1982a), and we observed a similar effect in the anoestrous lactating goats; the magnitude of the response to injections of $1500 \mathrm{ng}$ GnRH was reduced on the second day of treatment compared with the first.

Oestrus and ovulation were successfully induced in all of the lactating goats treated with GnRH. A preovulatory LH surge was detected in all but one of these and the exception was probably simply a consequence of ending the blood sampling too soon. The time of onset of the surge differed between the two treatment seasons. In one season the onset of the LH surge was very similar to the synchronized cycle $(39.6 \pm 3.3 \mathrm{~h})$. The reason for this variability is not known, but is similar to the variability in the mean time of onset of the preovulatory LH surge recorded in sheep of the same breed given identical GnRH treatments over two successive anoestrous seasons (B. J. McLeod \& W. Haresign, unpublished data), and in sheep of two different breeds given the same GnRH treatment in the same season (Hunter et al., 1986). Our two experiments were conducted at the same time of year, but differences in environmental conditions cannot be excluded.

Pheromonal contact between nannies may explain why one of the control anoestrous goats exhibited oestrus and ovulated (although with abnormal luteal function). Alternatively, the presence of the billy goat may have stimulated ovulation in this one animal, as has been observed for anoestrous creole goats (Chemineau, 1983). These goats demonstrate much less seasonality of breeding than do Saanens and reintroduction of the billy after 3 weeks of separation induces ovulation in the majority of anoestrous animals, irrespective of time of year.

Early studies with GnRH used large, single doses of 150 or $300 \mu \mathrm{g}$ to induce ovulation in sheep (Crighton et al., 1975). Although ovulation occurred in the majority of animals, luteal function was almost always abnormal or totally absent. The same approach has been tried in goats (Mizinga \& Verma, 1984), using a dose of $300 \mu \mathrm{g} \mathrm{GnRH}$. Ovulation was induced in 2 out of 3 goats, and in a separate group of 6 goats 2 pregnancies resulted. These limited observations suggest that single injections of GnRH may be more effective in goats than in sheep, but the response is variable and more work needs to be done. Other techniques have been used to induce ovulation in seasonally anoestrous goats. Treatment with progesterone followed by PMSG will advance the breeding season by 2 or 3 months (Ritar et al., 1984) but gives a poor response in early lactation and during the height of the anoestrous period (Corteel, 1975). Manipulation of photoperiod will also advance the breeding season (BonDurant et al., 1981) but requires a lengthy period of altered husbandry (artificial lighting) followed by several weeks of exposure to the billy goat. Melatonin treatment has been used to advance the breeding season in sheep (Nett \& Niswender, 1982). In goats, daily injection of melatonin for 104 days starting in June brought forward the onset of ovarian activity by 1 week only (Prandi et al., 1987), but the combination of altered lighting, melatonin treatment and introduction of the billy goat induced ovulation within 3 days, in early June (Chemineau et al., 1986).

In the present study, the mean ovulation rate after GnRH treatment was $2 \cdot 75 \pm 0 \cdot 25$. We are not aware of any data on ovulation rate for normally-cycling Saanen goats, but twin births are the norm and triplets are not uncommon. It is likely, therefore, that the observed ovulation rate was comparable to that occurring naturally in the breeding season. Superovulation was not induced by GnRH treatment. Five successful pregnancies during 2 seasons resulted in 3 sets of live twins, one set of still-born twins and one set of triplets. This kidding rate is similar to that normally observed in our Saanen goat herd. No pathological abnormalities were detected at post-mortem examination of the still-born fetuses.

In conclusion, multiple, small-dose injections of $\mathrm{GnRH}$ will reliably induce ovulation and normal luteal function in seasonally anoestrous goats at peak lactation. The ovulation rate achieved is normal, and, if care is taken to ensure maximum exposure to the billy goat, then good conception rates can be obtained. For the method to be of practical use, continuous infusion of GnRH is preferable to multiple injections. Preliminary experiments suggest that continuous infusion of GnRH 
(1500 ng/h) using an osmotic minipump will induce ovulation, and in one experiment 4 out of 4 goats treated in this manner are believed to be pregnant at the time of writing.

We thank J. S. Boyd of Glasgow University Veterinary School for performing the laparoscopies, Ann Docherty for skilled technical assistance and T. Hutchinson and Sandra Paton for care of the goats.

\section{References}

Baird, D.T., Swanston, I. \& Scaramuzzi, R.J. (1976) Pulsatile release of $\mathbf{L H}$ and secretion of ovarian steroids in sheep during the luteal phase of the estrous cycle. Endocrinology 98, 1490-1496.

BonDurant, R.H., Darien, B.J., Munro, C.J., Stabenfeldt, G.H. \& Wang, P. (1981) Photoperiod induction of fertile oestrus and changes in LH and progesterone concentrations in yearling dairy goats (Capra hircus). J. Reprod. Fert. 63, 1-9.

Chemineau, P. (1983) Effect on oestrus and ovulation of exposing creole goats to the male at three times of the year. J. Reprod.Fert. 67, 65-72.

Chemineau, P., Gauthier, D., Poirier, J.C. \& Saumande, J. (1982) Plasma levels of LH, FSH, prolactin, oestradiol $17 \beta$ and progesterone during natural and induced oestrous in the dairy goat. Theriogenology 17, 313-323.

Chemineau, P., Normant, E., Ravault, J.P. \& Thimonier, J. (1986) Induction and persistence of pituitary and ovarian activity in the out-of-season lactating dairy goat after a treatment combining a skeleton photoperiod, melatonin and the male effect. J. Reprod. Fert. 78, 497-504.

Corteel, J.M. (1975) The use of progestagens to control the oestrous cycle of the dairy goat. Annls Biol. anim. Biochim. Biophys. 15, 353-363.

Crighton, D.B., Foster, J.P., Haresign, W. \& Scott, S.A. (1975) Plasma LH and progesterone levels after single or multiple injections of synthetic LH-RH in anoestrous ewes and comparison with levels during the oestrous cycle. J. Reprod. Fert. 44, 121-124.

Foster, J.P. \& Crighton, D.B. (1974) Luteinizing hormone (LH) release after single injections of synthetic $\mathrm{LH}$ releasing hormone (LH-RH) in the ewe at three different reproductive stages and comparison with natural $\mathrm{LH}$ release at oestrus. Theriogenology 2, $87-100$.

Hunter, M.G., Southee, J.A., McLeod, B.J. \& Haresign, W. (1986) Progesterone pretreatment has a direct effect on GnRH-induced preovulatory follicles to determine their ability to develop into normal corpora lutea in anoestrous ewes. J. Reprod. Fert. 76, 349-363.

McLeod, B.J. \& Haresign, W. (1984) Induction of fertile oestrus in seasonally anoestrous ewes with low doses of GnRH. Anim. Reprod. Sci. 7, 413-420.

McLeod, B.J., Haresign, W. \& Lamming, G.E. (1982a) The induction of ovulation and luteal function in seasonally anoestrous ewes treated with small-dose multiple injections of GnRH. J. Reprod. Fert. 65, 215-221.

McLeod, B.J., Haresign, W. \& Lamming, G.E. (1982b) Response of seasonally-anoestrous ewes to smalldose multiple injections of $\mathrm{GnRH}$ with and without progesterone pretreatment. J. Reprod. Fert. 65, 223-230.

McLeod, B.J., Haresign, W. \& Lamming, G.E. (1983) Induction of ovulation in seasonally anoestrous ewes by continuous infusion of low doses of GnRH. $J$. Reprod. Fert. 68, 489-495.

Mizinga, K.M. \& Verma, O.P. (1984) LHRH-induced ovulation and fertility of anoestrous goats. Theriogenology 21, 435-446.

Nett, T.M. \& Niswender, G.D. (1985) Influence of exogenous melatonin on seasonality of reproduction in sheep. Theriogenology 17, 645-652.

Prandi, A., Romagnoli, G., Chiesa, F. \& Tamanini, C. (1987) Plasma prolactin variations and onset of ovarian activity in lactating anestrous goats given melatonin. Anim. Reprod. Sci. 13, 291-297.

Ritar, A.J., Maxwell, W.M.C. \& Salamon, S. (1984) Ovulation and LH secretion in the goat after intravaginal progestagen sponge-PMSG treatment. $J$. Reprod. Fert. 72, 559-563.

Scaramuzzi, R.J. \& Baird, D.T. (1977) Pulsatile release of luteinizing hormone and the secretion of ovarian steroids in sheep during anestrus. Endocrinology 101, 180 I-1806.

Received 19 October 1987 